\title{
Design of a Hybrid Wind-Solar Energy System for an Agro-industrial Residential Area in Bota-Limbe, Cameroon
}

\author{
Chu Donatus Iweh and Lemundem Marius \\ Department of Electrical and Electronic Engineering, University of Buea, Buea 63, Cameroon
}

\begin{abstract}
This paper proposes the most feasible technical and environmentally friendly hybrid power system configuration; a stand-alone hybrid wind-solar energy system with battery storage for a residential area of an Agro-industrial Company, Cameroon Development Cooperation (CDC), with headquarters in Bota-Limbe, south west region, Cameroon. The power network of the CDC Bota-Limbe Camp amongst other camps, which accommodates plantation workers, is plagued with challenges such as reliance on grid power which is unreliable, poor power quality which endangers home appliances and a spider webbed transmission system that poses as a threat to the lives of plantation workers. This paper addresses those concerns by designing a modular hybrid solar-wind renewable energy system for the camp. Limbe is a coastal area with proven existence of wind and solar resources. It is expected that the proposed system, if adopted and well implemented, will provide huge opportunities for the CDC in several other locations in Cameroon where there is adequate supply of renewable energy resources.
\end{abstract}

Key words: Hybrid power system, solar, wind, renewable energy resources, Agro-industrial Company.

\section{Introduction}

Electricity is essential for homes and industries daily operations hence must be efficiently generated via environmentally friendly technologies. For the camps and factories at the Cameroon Development Cooperation (CDC), obtaining reliable and cost effective electric power solutions for the expansion of their services both within urban and rural areas presents a very challenging problem. Currently in CDC, most of the camps are powered by the grid (ENEO-Cameroon) while those camps in remote areas have diesel generators installed. This implies a very high energy cost in running a camp and has thus resulted in very high tariff to the plantation workers. The grid, sometimes, is either not available or its extension can be extremely costly in remote area coupled with the losses experienced during transmission, hence the stand-alone systems are

Corresponding author: Chu Donatus Iweh, Ph.D. candidate, research fields: control of power systems, renewable energy solutions, smart grids using IoT applications. recommended especially for off-grid locations.

Wind and solar energy sources are the cheapest available natural resources for renewable energy and they best complement each other [1]; seasonal alternations with incorporated energy storage system (battery storage system in this case) to supply energy in case of shortfall by the wind solar hybrid system as a result of fluctuating weather conditions. Hence, for a site such as the CDC Camp at Bota-Limbe with abundant renewable energy resources (wind and solar), a more sustainable alternative to supply the 120 household plantation workers is to use renewable energy sources via a hybrid solar-wind energy system.

\section{System Architecture and Sizing}

This system is sized for 120 households with a total power of $0.501 \mathrm{MW}$ which feeds the CDC Camp Bota-Limbe, Cameroon. The system architecture adopted is alternating current (AC) coupled as shown in Fig. 1 below. In this system, the primary renewable sources are placed in parallel with a standby battery. 


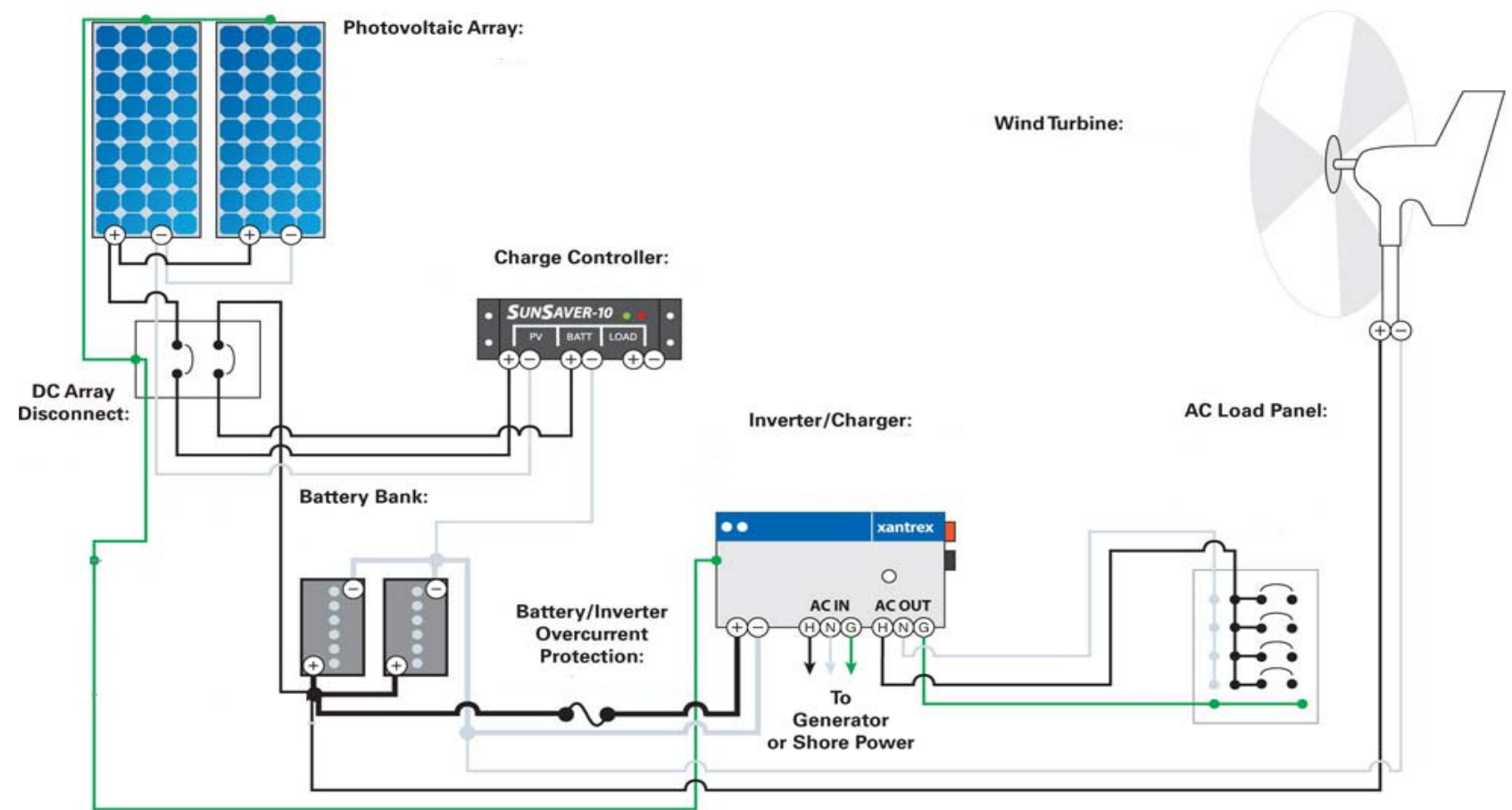

Fig. 1 Off-grid hybrid solar-wind system (HSWS) with battery backup [2].

The renewable sources (wind and photovoltaic (PV)) feed the direct current (DC) side of the network and the inverter converts the DC output of the renewable sources to AC which supplies the load.

\section{Limbe Solar-Wind Energy Potential Analysis}

Renewable energy resource assessment involves the task of selecting, installing and operating measurement equipment, as well as collecting and analysing associated data [3] once the measurement sites are identified. Analysis could also be done with maps showing the variability of these renewable energy resources [4] or analysing data for a particular location collected over a period of time.

In this paper, data which illustrate the typical weather in Limbe, based on a statistical analysis of historical hourly weather reports and model reconstructions from January 1, 1980 to December 31, 2016 were collected from Weather Spark and the average daily peak sunlight per month and wind speed hours per month were plotted in order to better appreciate the variation of wind/solar resources in Limbe. Fig. 2 shows the variation of wind/solar resources in Limbe.

Fig. 2 indicates that the month of August is the windiest month. The graph corresponds to results obtained by Arreyndip et al. [4] in their research carried with data from National Aeronautics and Space Administration (NASA) for a period of 31 years. The average daily peak sunlight hours of Douala [7] (76 km away from Limbe), were used as both towns share the same solar irradiation map. It was deduced from the graph that the annual average peak sunlight hours per day $\left(\mathrm{PSH}_{P V}\right)$ for Limbe were 3.29 hours, a justification of the existence of solar resources in this area. The figure clearly exposes the complimentary role these resources (wind/solar) play in the hybrid renewable energy system.

The average daily wind speed hours analysis at a rated wind speed of $6 \mathrm{mph}(5.3 \mathrm{~m} / \mathrm{s})$ of the town of Limbe was carried out at 10 meters above ground level [8]. Due to the challenges involved in measuring wind speed at different landscapes and altitudes, the following equation was used in determining the wind speed directly with data collected from NASA. 


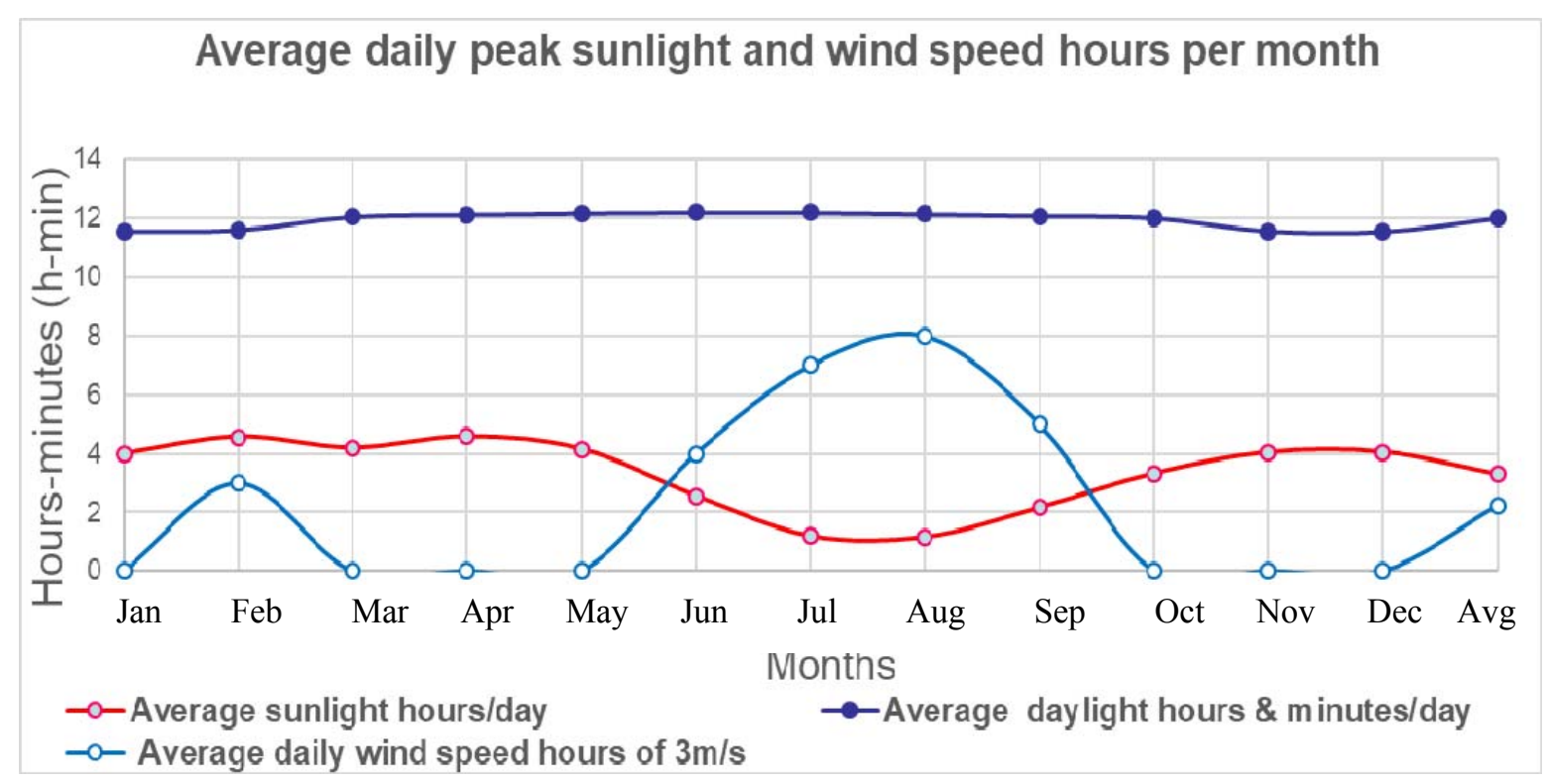

Fig. 2 Average weather in Limbe-Cameroon [5, 6].

$$
V_{T}=V_{R}\left(\frac{h_{T}}{h_{R}}\right)^{\alpha}
$$

where, $V_{R}$ is the measured reference wind speed, $V_{T}$ is the wind velocity calculated theoretically and $\alpha$ represents the coefficient of friction [9] due to ground roughness. Wind speed analysis in Limbe [8] at 10 meters above the ground indicates an annual average peak wind speed hour per day $\left(P W H_{W T}\right)$ of 2.25 hours at a wind speed of $3 \mathrm{~m} / \mathrm{s}$. For coefficient of friction, $\alpha$, of 0.5 in a terrain with buildings, the calculated wind speed at an elevation of 30 meters from the ground was $5.19 \mathrm{~m} / \mathrm{s}$.

Analysis of the local solar irradiation and wind speed data of Limbe, positions solar energy resource as the prevailing renewable energy resource over wind owing to the fact that Limbe is close to the equator (latitude $4.02^{\circ}$ North and longitude $9.21^{\circ}$ East) with high solar radiation. Hence, it is legitimate to set the PV system as the predominant energy source over the wind energy system. The present hybrid solar-wind system (HSWS) design shares the system loads in a ratio of 2:3 for the wind turbine (WT) and PV system respectively.

\section{Electrical Load Demand for the CDC Bota-Limbe Camp}

Before getting into the design, sizing up the realities and challenges of living off the grid becomes imperative. Instead of meeting the home's annual demand, a stand-alone system must be able to meet the daily energy requirements of the loads. Determining the home's daily and seasonal energy usage, along with considering the daily and seasonal availability of the solar and wind resources at the installation site, allows designers to estimate the PV array, wind farm, battery bank, charge controller and inverter specifications.

The main research method used in this paper was theoretical data analysis on the trends in electric appliance development technologies and consumption trends of households at Bota Camp. Data about the intensity of electric appliance usage and load power characteristics (active power and the power factor) were collected through on-site observation, technical data from electric appliance producers, and research results from relevant data sources $[5,6]$. A sample load analysis of the major appliances that constitute the Bota Camp together with their distribution percentages is presented in Table 1.

Many appliances, especially those with wireless remote controls, draw power even when turned off and called phantom or standby loads [10]. While each load may be small, the energy consumption of multiple 
appliances over a 24-hour period can add up and be quite large. Table 2 depicts the analysis of the system home appliances (typical loads when off but plugged in) with significant standby load power.

\section{Hybrid System Components and Sizing}

In sizing components for this system, the number of units to be used and operating hours were used in the calculations. Description of these components is given in the following sections.

\subsection{Photovoltaic Array}

Solar power at the selected site is higher than the wind power. The REC TWINPEAK $285 \mathrm{~W}$ PV module (REC285TP) from Ref. [11] with lifetime of 20 years was chosen for the design. There was no tracking system in the PV system.

The total daily PV array energy $E_{P V}$ and current $I_{P V}$ requirement of the system:

$$
\begin{gathered}
E_{P V}=E_{a v_{-} d} / 80 \% \\
I_{P V}=E_{P V} /\left(P S H_{P V} \times V_{D C_{s y s}}\right)
\end{gathered}
$$

The required number of series connected $\mathrm{PV}$ modules will be:

$$
\begin{gathered}
N_{P V_{-} \text {series }}=V_{D C_{-} \text {sys }} / V_{m} N_{P V_{-} \text {series }}=22.692 \\
\cong 23 \mathrm{PV} \text { modules }
\end{gathered}
$$

Likewise, the required number of series connected PV modules will be:

$$
\begin{gathered}
N_{P V_{-} \text {parallel }}=I_{P V} / I_{m} N_{P V_{\_} \text {parallel }}=60.4435 \\
\cong 60 \mathrm{PV} \text { modules }
\end{gathered}
$$

Hence, the total number of PV modules required for the PV system is:

$$
\begin{gathered}
N_{P V_{-} \text {total }}=N_{P V_{-} \text {parallel }} \times N_{P V_{-} \text {series }} N_{P V_{-} \text {total }} \\
=1380 \mathrm{PV} \text { modules }
\end{gathered}
$$

\subsubsection{Solar Charge Controllers}

The charge controllers for each block were sized by multiplying the short circuit current of the modules connected in parallel by a safety factor $F_{\text {save }}=1.25$. In the design, each block of modules carries a solar charge controller. The calculated current rating per block was done using the equation below:

$I_{\text {Controller }}=1.25 \times I_{P V \_S C} \times N_{P V \_p a r a l l e l}=161 \mathrm{~A}$

The Cyrix-I 24/48V 200A [12] solar charge controller was selected for this system.

\subsection{Wind Turbine}

A $6 \mathrm{~kW}$ wind turbine (KW6) from KINGSPAN wind $[13,14]$ is chosen for this system. Availability of energy from the wind turbine depends greatly on wind variations. Thus, wind turbine rating is generally much higher compared to the average electrical load. In this paper, 6KW WT (KW6) wind generator model was

\begin{tabular}{|c|c|c|c|c|c|c|c|c|c|c|}
\hline \multicolumn{11}{|c|}{ Standby loads } \\
\hline \multirow[b]{2}{*}{ Appliance } & \multirow{2}{*}{$\begin{array}{l}\text { Standby } \\
\text { load power } \\
(\mathrm{W})^{*}\end{array}$} & \multirow{2}{*}{$\begin{array}{l}\text { Quan } \\
\text { tity }\end{array}$} & \multirow{2}{*}{$\begin{array}{l}\text { Active } \\
\text { power } \\
(\mathrm{W})\end{array}$} & \multirow{2}{*}{$\begin{array}{l}\text { Power } \\
\text { factor }\end{array}$} & \multirow{2}{*}{$\begin{array}{l}\text { Daily } \\
\text { usage (h) }\end{array}$} & \multirow{2}{*}{$\begin{array}{l}\text { Apparent } \\
\text { power } \\
\text { (VA) }\end{array}$} & \multirow{2}{*}{$\begin{array}{l}\text { Energy } \\
\text { (Wh) }\end{array}$} & \multirow{2}{*}{$\begin{array}{l}\text { Dist. \% } \\
\text { over } 120 \\
\text { homes }\end{array}$} & \multicolumn{2}{|c|}{ Total load analysis } \\
\hline & & & & & & & & & $\begin{array}{l}\text { Apparent } \\
\text { power (VA) }\end{array}$ & $\begin{array}{l}\text { Energy } \\
\text { (Wh) }\end{array}$ \\
\hline Phone charger & 1 & 4 & 4 & 0.62 & 12 & 6.4516 & 77.42 & 100 & 774.19 & 9,290 \\
\hline Stationary radio & 1 & 1 & 1 & 0.8 & 24 & 1.25 & 30 & 100 & 150 & 3,600 \\
\hline TV & 1.5 & 1 & 1.5 & 0.7 & 24 & 2.1429 & 51.43 & 100 & 257.14 & 6,171 \\
\hline Computers \& laptop & 5 & 1 & 5 & 0.56 & 24 & 8.9286 & 214.3 & 10 & 107.14 & 2,571 \\
\hline Woofer & 2 & 1 & 2 & 0.8 & 24 & 2.5 & 60 & 80 & 240 & 5,760 \\
\hline Electric fan & 1 & 1 & 1 & 0.8 & 24 & 1.25 & 30 & 5 & 7.5 & 180 \\
\hline DVD player & 1.5 & 1 & 1.5 & 0.8 & 24 & 1.875 & 45 & 80 & 180 & 4,320 \\
\hline Electric iron & 10 & 1 & 10 & 0.98 & 24 & 10.204 & 244.9 & 10 & 122.45 & 2,939 \\
\hline Total & & & 26 & & & 34.602 & 753 & & $1,838.4$ & 34,832 \\
\hline
\end{tabular}
used with rated capacity of $6 \mathrm{~kW}$ and a turbine lifetime of 20 years. For optimum solutions, the use of 1, 2, 4 and 6 units of wind turbine was considered.

The total daily wind farm energy $E_{W T}$ and current $I_{W T}$ requirement of the system:

$$
\begin{gathered}
E_{W T}=E_{a v_{-} d} / 20 \% \\
I_{W T}=E_{W T} /\left(P W H_{W T} \times V_{D C_{s y s}}\right)
\end{gathered}
$$

Table 1 Load analysis for standby loads at Bota-Limbe Camp. 
Table 2 Load analysis for resistive/inductive loads at Bota-Limbe Camp.

\begin{tabular}{|c|c|c|c|c|c|c|c|c|c|c|c|c|c|c|}
\hline \multicolumn{15}{|c|}{ Resistive loads } \\
\hline \multirow[b]{2}{*}{ Common loads } & \multirow[b]{2}{*}{$\begin{array}{l}\text { Load type } \\
(\mathrm{R} / \mathrm{C} / \mathrm{L})^{*}\end{array}$} & \multirow{2}{*}{$\begin{array}{l}\text { Power } \\
\text { rating } \\
(\mathrm{W})\end{array}$} & \multirow[b]{2}{*}{ Quantity } & \multirow{2}{*}{$\begin{array}{l}\text { Active } \\
\text { power } \\
\text { (W) }\end{array}$} & \multirow[b]{2}{*}{$\begin{array}{l}\text { Power } \\
\text { factor }\end{array}$} & \multirow{2}{*}{$\begin{array}{l}\text { Daily } \\
\text { usage } \\
\text { (h) }\end{array}$} & \multirow{2}{*}{$\begin{array}{l}\text { Apparent } \\
\text { power } \\
\text { (VA) }\end{array}$} & \multirow[b]{2}{*}{$\begin{array}{l}\text { Energy } \\
\text { (Wh) }\end{array}$} & \multirow{2}{*}{$\begin{array}{l}\text { Dist. \% } \\
\text { over } 120 \\
\text { homes }\end{array}$} & \multicolumn{2}{|c|}{ Total load analysis } & \multirow[b]{2}{*}{$\begin{array}{l}\text { Surge } \\
\text { factor }\end{array}$} & \multicolumn{2}{|c|}{ Surge power analysis } \\
\hline & & & & & & & & & & $\begin{array}{l}\text { Apparent } \\
\text { power } \\
\text { (VA) }\end{array}$ & $\begin{array}{l}\text { Energy } \\
\text { (Wh) }\end{array}$ & & $\begin{array}{l}\text { Apparent } \\
\text { power (VA) }\end{array}$ & $\begin{array}{l}\text { Energy } \\
\text { (Wh) }\end{array}$ \\
\hline Incandescent bulb & $\mathrm{R}$ & 60 & 2 & 120 & 1 & 6 & 120 & 720 & 100 & 14,400 & 86,400 & 1 & 14,400 & 86,400 \\
\hline \multicolumn{15}{|l|}{ Not common loads } \\
\hline Electric iron & $\mathrm{R}$ & 1,000 & 1 & 1,000 & 1 & 2 & 1,000 & 2,000 & 50 & 60,000 & 120,000 & 1 & 60,000 & 120,000 \\
\hline \multicolumn{15}{|l|}{ Common loads } \\
\hline Fluorescent lamp & $\mathrm{R} / \mathrm{L}$ & 36 & 2 & 72 & 0.58 & 6 & 124.138 & 744.83 & 100 & $14,896.55$ & $89,379.3$ & 3.5 & $52,137.931$ & 312,828 \\
\hline $\begin{array}{l}\text { Phone \& device } \\
\text { charger }\end{array}$ & $\mathrm{R} / \mathrm{C}$ & 10 & 4 & 40 & 0.62 & 5 & 64.5161 & 322.58 & 100 & $7,741.935$ & $38,709.7$ & 3.5 & $27,096.774$ & 135,484 \\
\hline Stationary radio & $\mathrm{R} / \mathrm{L}$ & 5 & 1 & 5 & 0.8 & 7 & 6.25 & 43.75 & 100 & 750 & 5,250 & 3.5 & 2,625 & 18,375 \\
\hline TV & $\mathrm{R} / \mathrm{L}$ & 50 & 1 & 50 & 0.7 & 5 & 71.4286 & 357.14 & 100 & $8,571.429$ & $42,857.1$ & 3.5 & 30,000 & 150,000 \\
\hline Sub total & & & & 167 & & & & $1,468.3$ & & $31,959.92$ & 176,196 & & $111,859.71$ & 616,686 \\
\hline \multicolumn{15}{|l|}{ Not common loads } \\
\hline Woofer & $\mathrm{R} / \mathrm{L}$ & 53 & 1 & 53 & 0.8 & 6 & 66.25 & 397.5 & 80 & 6,360 & 38,160 & 3.5 & 22,260 & 133,560 \\
\hline Refrigerator & $\mathrm{R} / \mathrm{L}$ & 100 & 1 & 100 & 0.8 & 8 & 125 & 1,000 & 10 & 1,500 & 12,000 & 3.5 & 5,250 & 42,000 \\
\hline Electric fan & $\mathrm{R} / \mathrm{L}$ & 60 & 1 & 60 & 0.8 & 8 & 75 & 600 & 5 & 450 & 3,600 & 3.5 & 1,575 & 12,600 \\
\hline \multirow[t]{2}{*}{ DVD player } & $\mathrm{R} / \mathrm{L}$ & 25 & 1 & 25 & 0.8 & 8 & 31.25 & 250 & 80 & 3,000 & 24,000 & 3.5 & 10,500 & 84,000 \\
\hline & & & & 303 & & & & $2,595.7$ & & $12,702.86$ & $81,938.6$ & & 44,460 & 286,785 \\
\hline Total & & & & 1,590 & & & & 6,784 & & $119,062.8$ & 464,535 & & $230,719.71$ & $1,109,871$ \\
\hline
\end{tabular}

* $\mathrm{R}$-active power load, L-reactive (inductive) power load, $\mathrm{C}$-reactive (capacitive) power load. 
For a WT module operated at DC output voltage of $300 \mathrm{VDC}$ at $5 \mathrm{~m} / \mathrm{s}$, the WT output current will be:

$$
I_{W T_{\text {mod }}}=P_{W T_{\text {mod }}} / V_{W T_{\text {mod }}} I_{W T_{\text {mod }}}=3.405 \mathrm{~A}
$$

For a rated output power of one WT module $P_{W T_{-} \bmod }$ at $5 \mathrm{~m} / \mathrm{s}$ is $1.2157 \mathrm{~kW}$, the total number of parallel connected WT will be:

$$
\begin{aligned}
N_{W T \_p a r a l l e l}=I_{W T} / I_{W T \_m o d} & N_{W T \_p a r a l l e l} \\
& =39.85497044 \cong 40 \mathrm{WT} \text { modules }
\end{aligned}
$$

Since the WT module DC output voltage is twice the system DC voltage $\left(N_{W T_{\text {series }}}=5\right)$, hence, the total number of WT required for the WT system is:

$$
\begin{gathered}
N_{W T_{\text {_t}} \text { total }}=N_{W T_{\text {_p }} \text { arallel }} \times N_{W T_{\text {_sseries }}} N_{W T_{-} \text {total }} \\
=200 \mathrm{~W} \text { ind Turbines }
\end{gathered}
$$

\subsection{Battery Bank}

For storage purposes, the battery bank is used in the hybrid system design. Commercially available models such as STT Series low maintenance tubular flooded batteries STT2V800 [15] 2 volts cells with 20 years design life were selected for the application. The battery stack contains a number of batteries $(6,8,12$, or 36) for sensitivity and optimization purposes. Each battery string contains 4 batteries.

\subsection{Power Inverter}

The total apparent power (continuous supply and surge capability) through the inverter is:

$$
P_{i n v}=P_{P V}+P_{W T}=376.105104 k V A
$$

The Conext ${ }^{\mathrm{TM}} \mathrm{XW}$ Series $6 \mathrm{kVA}$ inverter [16] by Schneider electric was selected and connected across each system block. The output AC voltage and current from inverter are $230 \mathrm{~V}$ and $26.1 \mathrm{~A}$, hence, it is synchronized with the system load characteristics.

Table 3 PV and WT module specifications [11, 14].

\begin{tabular}{llll}
\hline \multicolumn{2}{c}{ PV module } & \multicolumn{2}{c}{ WT module } \\
\hline Electrical data & REC285TP & Electrical data & KW6 \\
\hline Nominal power (Wp) & 285 & Rated power (1 min avg at $11 \mathrm{~m} / \mathrm{s})$ & $5.2 \mathrm{~kW}$ \\
Watt class sorting (W) & $0 /+5$ & Peak power $(1 \mathrm{~min}$ avg) & $6.1 \mathrm{~kW}$ \\
Nominal power voltage (V) & 32.1 & Reference annual energy production at & $8,949 \mathrm{kWh}$ \\
Nominal power current (I) & 8.9 & $5 \mathrm{~m} / \mathrm{s}$ at hub height & $1.2157 \mathrm{~kW}$ \\
Open circuit voltage (V) & 39.5 & Rated power at $5 \mathrm{~m} / \mathrm{s}$ & $5.5 \mathrm{~m}$ \\
Short circuit current (A) & 9.54 & Rotor diameter & $9 \mathrm{~m} / 11 \mathrm{~m} / 15 \mathrm{~m} / 20 \mathrm{~m}$ \\
Panel efficiency & 17.3 & Tower options & Battery charge, $48 \mathrm{~V}, 120 \mathrm{~V}, 300 \mathrm{~V}$ \\
Dimension-area $1.65 \mathrm{~m}^{2}(\mathrm{~mm})$ & $1,665 \times 991 \times 38$ & Coltages available & $3.5 \mathrm{~m} / \mathrm{s}$ \\
Maximum system voltage $(\mathrm{V})$ & 1,000 & Cut out speed & None-continuous operation \\
Max. series fuse rating (A) & 25 & Generator & Brushless direct drive permanent \\
\hline
\end{tabular}

Table 4 Battery module specification.

\begin{tabular}{ll}
\hline & Battery module \\
\hline Technical data & STT2V800 \\
\hline Cell voltage $V_{\text {cell }}(\mathrm{V})$ & 2 \\
8 hr. Ah rate $I_{\text {cell }}(\mathrm{Ah})$ & 865 \\
Cell dimensions & $8.27 \times 7.52 \times 27.6$ \\
Weight/electrolyte $(\mathrm{lb})$. & 141 \\
Electrolyte weight $(\mathrm{lb})$. & 35.2 \\
Electrolyte $($ Gallons) & 3.4 \\
Number of poles & 4 \\
Short circuit current $(\mathrm{A})$ & 6,200 \\
\hline
\end{tabular}




\section{Plant Characteristics and Configuration}

The electrical design of each sub unit (PV and WT) is considered on a case by case basis, as each site poses unique challenges and constraints. International standards and country-specific electrical codes were used in order to ensure that the installation was safe and compliant. Here, the technical studies of the hybrid solar-wind transmission network were carried out based on the component specifications. Technical information about the installation system at the Bota-Limbe Camp is summarised in Table 5.
The total capacity of the hybrid system is 0.501 MW. Analysis on the area of land needed for the installation of both sub systems revealed that the solar sub system of identical solar panels of ratings $285 \mathrm{~W}$ will occupy over 0.47 acres $\left(1,912.35 \mathrm{~m}^{2}\right)$ of land only. The WT farm will require a minimum of 0.26 acres $\left(1,045 \mathrm{~m}^{2}\right)$ of land. Hence, the HSWS farm will be distributed into 100 identical blocks of $6 \mathrm{~kW}$ inverter capacity, in a ratio of $2: 3$ for WT and PV systems respectively. Table 6 summarizes the modular system configuration.

Table 5 Characteristics of the modular system (hybrid solar-wind renewable energy system).

\begin{tabular}{lll}
\hline System parameter & PV & WT \\
\hline Total power (kW) & 331.2 & 204.3 \\
Percentage inverter loading (\%) & 60 & 40 \\
Number of inverter block & 60 & 40 \\
Total inverter capacity (kW) & 360 & 240 \\
Total power per block (kW) & 5.52 & 5.11 \\
Total number of PV/WT modules per block & 23 & 5 \\
Total number of PV/WT modules & 1,380 & 200 \\
Total current per block & 109.25 & 106.41 \\
Number of series/parallel modules per block & 1 & 1 \\
Percentage battery loading (\%) & 23 & 33.333 \\
Number of battery modules & 66.667 & 1,200 \\
Total number of battery modules & 2,400 & 5 \\
Number of battery modules per block & & 3,600 \\
Total battery (MWh)/current (kAh) capacity & 40 & 30 \\
Number of series/parallel battery modules/block & 4.15 & 86.5 \\
\hline
\end{tabular}

Table 6 Technical data of the off-grid hybrid solar-wind system.

\begin{tabular}{lcl}
\hline & System parameters \\
\hline Hybrid system power $(\mathrm{kW})$ & 501.0667 \\
PV system power $(\mathrm{kW})$ & 308.0328 & \\
WT system power $(\mathrm{kW})$ & 193.0339 & 48 \\
DC voltage PV/WT $(\mathrm{VDC})$ & 48 & \\
AC voltage $(\mathrm{VAC})$ & $230 / 400$ \\
Battery capacitance $(\mathrm{kAh})$ & 114.9011 \\
Inverter power $(\mathrm{kVA})$ & 600 \\
\hline
\end{tabular}

Table 7 Load sharing in the hybrid solar-wind design.

\begin{tabular}{lllll}
\hline System type & Load sharing percentage & Total energy $(\mathrm{kWh})$ & $\begin{array}{l}\text { Daily average peak } \\
\text { energy hours }(\mathrm{h})\end{array}$ & Total power $(\mathrm{kW})$ \\
\hline Photovoltaic (PV) & $60 \%$ & $1,013.42799$ & 3.29 & 308.032822 \\
Wind turbine (WT) & $40 \%$ & 434.32628 & 2.25 & 193.033902 \\
Hybrid solar-wind & $100 \%$ & $1,447.75427$ & --- & 501.066725 \\
\hline
\end{tabular}



Residential Area in Bota-Limbe, Cameroon
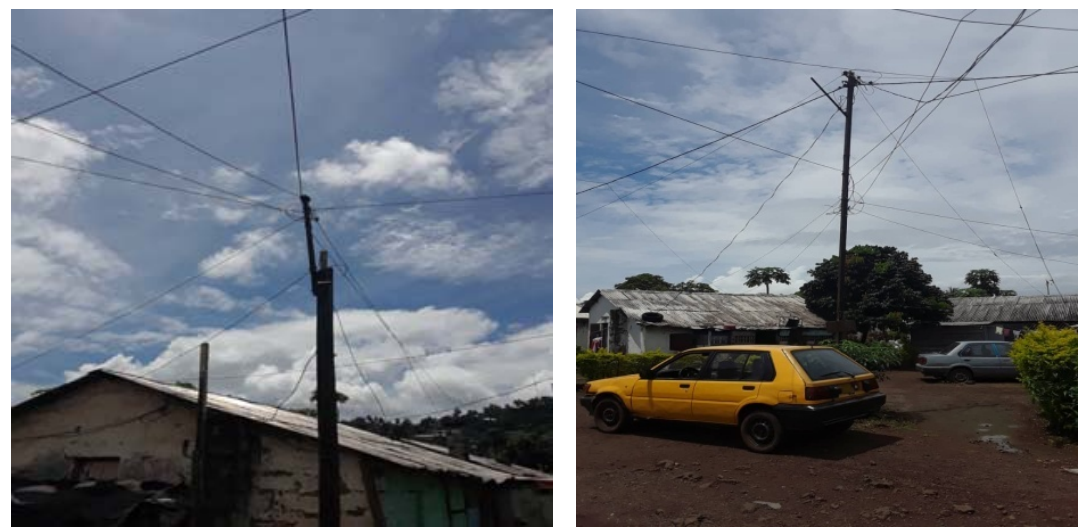

Fig. 3 Spider webbed wiring at Bota-Limbe Camp.
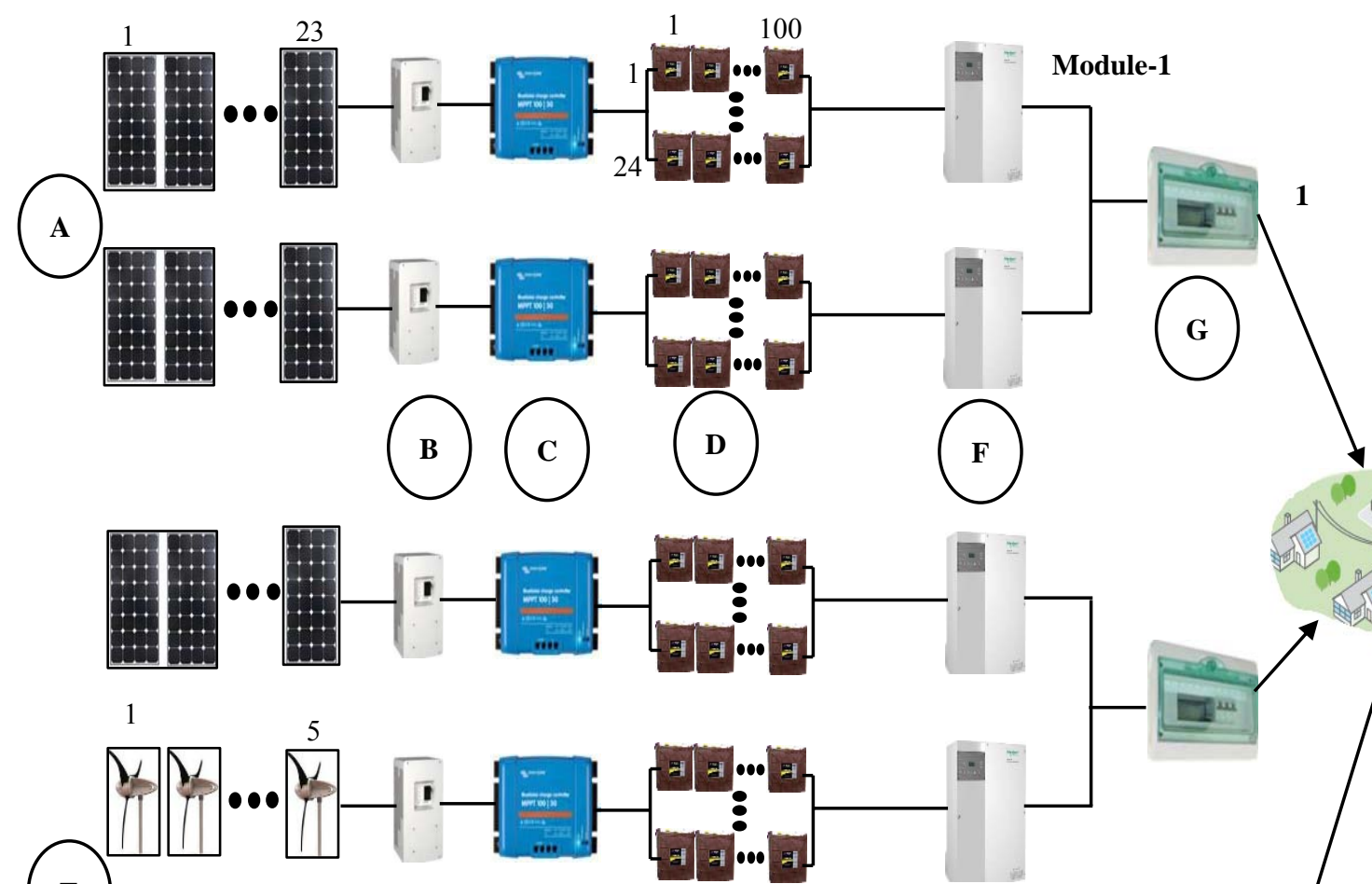

E
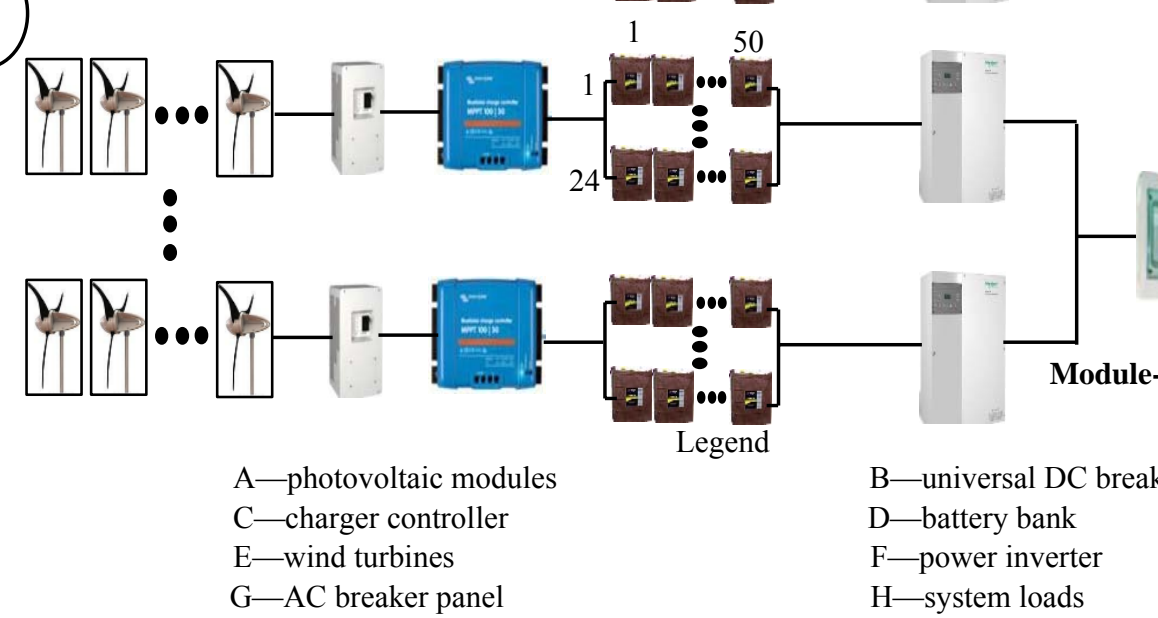

Module-100

Legend

B-universal DC breaker panel

D_-battery bank

$\mathrm{F}$-power inverter

$\mathrm{H}$-system loads

Fig. 4 Proposed wiring diagram of the hybrid solar-wind system for Bota-Limbe Camp. 
Appropriately rated switchgear and protection systems were integrated in the system in order to provide disconnection, isolation, earthing and protection. On the output side of the inverters, provision of a switch disconnector was recommended as a means to isolate the PV array. AC circuit breakers of $100 \mathrm{~A} / 230 \mathrm{~V}$ were used to interconnect modules in the system. The proposed architecture of the hybrid PV-wind renewable energy system eliminating the spider webbed transmission network currently existing in the CDC Bota Camp is presented in Fig. 4.

\section{Conclusion}

From the wiring diagram, the proposed system is an efficient energy distribution system with generation units (PV and WT) which are interconnected in a way as to guarantee local power delivery to the plantation workers at the Bota-Limbe Camp at minimal system losses. Hence, a modular system evenly distributed over the camp based on the site landscape and land availability has been developed and proposed. The design procedure developed in this paper is a product of modern technologies simulated and implemented in a number of HSWS designs around the world. An extensive literature review of the system components with a special focus on off grid systems was conducted after which similar steps were employed in this paper. The developed procedures were used in the design of the hybrid wind-solar system for the Bota-Limbe Camp in Fako Division, south-west region of Cameroon.

\section{References}

[1] Somkene, N. M., Iqbal, M. T., and Amy, H. 2010. "Design of a $1.5 \mathrm{~kW}$ Hybrid Wind/Photovoltaic Power System for a Telecoms Base Station in Remote Location of Benin City, Nigeria.” Benin City.
[2] Home Power Inc. 2018. "Home Power." Accessed July 7, 2018.

https:/www.homepower.com/solar-electricity/equipment -products.

[3] Neils, M. G. 2013. Planning and Development of Wind Farms: Wind Resource Assessment and Siting. DTU wind energy report.

[4] Arreyndip, N. A., Ebobenow, J., and Afungchui, D. 2016. "Wind Energy Potential Assessment of Cameroon's Coastal Region for the Installation of an Onshore Wind Farm." Heliyon 2 (11).

[5] Jakušenoks, A., and Laizāns, A. 2015. "Impact of Household Electric Energy Usage Trends on Electrical Power Supply Net Power Factor." Research for Rural Development 1: 253-7.

[6] Rasmussen, N. 2011. "Understanding Power Factor, Crest Factor, and Surge Factor." Schneider Electric.

[7] ClimaTemps.com. 2017. "Sunshine \& Daylight Hours in Douala, Cameroon." Accessed July 7, 2018. www.douala.climatemps.com/sunliht.php.

[8] Cedar Lake Ventures, I. "Average Weather in Limbe-Cameroon.” Weather Spark. Accessed July 7, 2018. https:/weatherspark.com/y/61812/Average-Weather-in-L imbe-Cameroon-Year-Round.

[9] Boaro, M., Fuselli, D., Angelis, F. D., Liu, D., Wei, Q., and Piazza, F. 2013. "Adaptive Dynamic Programming Algorithm for Renewable Energy Scheduling” Cognitive Computat. 264 (5).

[10] AEE Solar. 2016. "The Essential Guide to Everything Solar: 35th Annual Catalog."

[11] REC. 2016. "REC TWINPEAK Series: Premium Solar Panels with Superior Performance."

[12] Victron Energy B. V. 2013. "Cyrix-i 200A-400A 12/24V and 24/48V." The Netherlands.

[13] Kingspan Wind. 2017. Off-Grid Systems Guide.

[14] Bauer, L., and Silvio, M. 2019. "Kingspan Renewables Ltd.” Kingspan Renewables Ltd. Accessed March 2019. https:/en.wind-turbine-models.com/turbines/666-kingspa n-renewables-kw6.

[15] SBS Storage Battery System LLC. "STT Series Low Maintenance Tubular Flooded Batteries OPzS 2 Volt Cells (110-3,585 Ah)."

[16] Schneider Electric. 2013. "Grid-Tie, Off-Grid Solar and Backup Power Solutions for Residential and Commercial Installations." 